\title{
The influence of human character strengths on life satisfaction
}

\section{Orose Leelakulthanit}

\author{
NIDA Business School, \\ National Institute of Development Administration, \\ 118 Seri Thai Road, Bangkapi, Bangkok 10240, Thailand \\ orose@nida.ac.th
}

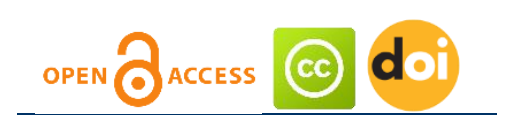

Article history:

Received: March 22, 2021

1st Revision: October 12,

2021

Accepted: November 12, 2021

\section{JEL classification: M10}

DOI:

10.14254/jems.2021.6-2.4

\begin{abstract}
As is well known, the characteristics of being human are important to all of us because they signify our basic identity as individuals. It can be asked, however, which of those characteristics are related to our well-being as that is assessed by our life satisfaction. It is the intention of this study to explore the connections among human character strengths and life satisfaction. The human character strengths studied here include curiosity, love of learning, wisdom, having a "big picture perspective," self-awareness, honesty, kindness, social intelligence, intangible values, gift giving, social responsibility, and hope and humor. A total of 498 responses were collected from adult shoppers in Bangkok, Thailand. The results of the multiple regression analysis indicated that among the various human character strengths, as well the demographic characteristics, wisdom, self-awareness, household income, hope, education, social responsibility, and intangible values have positive impacts on life satisfaction The only negative element that was seen to have a negative influence on life satisfaction was curiosity. Further analyses of the significant determinants of life satisfaction for those with varying household incomes and levels of education were carried out and are discussed in this article.
\end{abstract}

Keywords: human characteristics, character strengths, life satisfaction, well-being, quality of life. 


\section{Introduction}

Character strengths are the positive characteristics of people and can be seen in our thoughts, feelings, and behaviors, and according to Park, Peterson, and Seligman (2004), these can contribute to the development of individuals (Park, Peterson \& Seligman, 2004). Park et al. (2013) have put forward the notion that character strengths are a multidimensional concept; that is, they can be thought of as a set of positive attitudes because we are all able to embody any of them. According to Niemiec and McGrath (2019), studies have shown that character strengths help us to manage the problems we encounter in life with greater effectiveness. For example, possessing a strong character or having strong character strengths has been connected with experiencing less stress and improved ability to cope with the problems found in the workplace, with less friction in the classroom, less depression, and fewer illness symptoms. These are among the many settings in which character strengths have been explored. Moreover, research has also demonstrated the many positive benefits of using character strengths in the physical, psychological, emotional, social, and spiritual areas of life. The benefits of character strengths have also been demonstrated in many industries-especially business and education-but also in healthcare, coaching, and psychotherapy, and counseling, among others. The specific benefits of character strengths have been linked with each of the main elements of well-being; that is, positive emotions, engagement, meaning, positive relationships, and accomplishment, and they have additionally been connected with many other benefits that help us experience the more positive aspects of our life, such as self-acceptance, autonomy, goal progress, physical health, passion, and resilience.

Niemiec and McGrath (2019) have pointed out that when we are satisfied with the way in which our life is going, we can use character strengths to help us see what is best in ourselves and in others. On the other hand, when things are not going well, we can use our character strengths to find a balance in the struggles we are facing and change our focus from the negative to the positive. In this way, we can avoid being too self-critical by focusing on our strengths rather than upon our deficits. For this reason, it is likely that character strengths will lead to people's well-being. It is the intention of this study to investigate which human character strengths from those chosen contribute to people's well-being as measured by life satisfaction. These selected character strengths include curiosity, love of learning, wisdom, having a "big picture perspective," self-awareness, honesty, kindness, social intelligence, intangible values, gift giving, social responsibility, and hope and humor.

\section{Literature review}

\section{Curiosity}

Berlyne (1960) has described curiosity as an emotional state that can be caused by conceptual conflicts or insecurity, following which the individual searches for information to resolve this uncertainty. As a result of this resolution of uncertainty, the person is able to restructure his or her knowledge and learn more about life and how to achieve greater life satisfaction. Frijda (1994) has also discussed curiosity in terms of emotion, and some other authors (e.g., Clore, Ortony and Foss, 1987) treat it as a cognitive state; and Depue (1996) has described curiosity as a "core motivational mechanism of the biologically-based system of reward sensitivity" (Depue, 1996). Ryan and Deci (2000) in turn discussed curiosity within the area of intrinsic motivation, which can be considered to be central to a person's well-being.

Many (e.g., Ben-Zur, 2002; Boyle, 1983) authors have asserted that curiosity not just a passing condition but is a more permanent personality trait that is expressed in a variety of situations. Curiosity is related to seeking information and exploring the environment, anxiety regarding threatening situations due to fear, and anger against aggressive action (Ben-Zur, 2002). Kashdan and Steger (2007) indicated that curiosity is a mechanism for achieving and maintaining high levels of well-being and meaning in life. They found that on days when people are more curious, they reported a greater number of growth-oriented behaviors and life satisfaction. Additionally, Jovanovic and Brdaric (2012) found that adolescents that demonstrated high levels of curiosity exhibit higher levels of life satisfaction and positive affect, and a greater sense of purpose in life and hope than adolescents that have either low or an average amount of curiosity. Thus, it can be hypothesized that curiosity is positively related to people's life satisfaction.

\section{Love of learning}

Some authors (e.g., Lyubomirsky et al., 2005) have suggested that engaging in activities related to happiness (especially intentional activities) is one way to create psychological well-being. Vallerand (2012) for example agrees with this position and has pointed out that being passionate about an activity leads to a deeper involvement in that activity, and that this can have sustainable 
positive effects on a person's sense of well-being. Because people that are passionate about what they are doing typically are involved in what they are doing for several hours every week, they may experience positive affective experiences that will provide them with a sense of well-being. However, not all intentional activities bring about a person's sense of well-being. As Vallerand (2012) has indicated, there are two types of passion. Although one type, called harmonious passion, is expected to create sustainable psychological well-being through the repeated experience of positive emotions during one's engagement in a task, a second type of passion, called obsessive, is not expected to produce such effects and may even bring about negative emotions and hinder the achievement of a happy and balanced life. It is hypothesized in this study that love of learning will lead to positive life satisfaction.

\section{Wisdom}

Wisdom has been found to be positively associated with a person's life satisfaction (Ardelt, 2000; Baltes, Staudinger, Maercker and Smith, 1995; Jason et al., 2001; Mickler and Staudinger, 2008; Perry et al., 2002; Takahashi and Overton, 2002), and it has been suggested that wisdom affects life satisfaction more than a person's socioeconomic position, or his or her physical environment, physical health, and social relations (Ardelt, 2000; Ferrari, Kahn, Benayon and Nero, 2011; Jason et al., 2001; Perry et al., 2002). On the other hand, evidence also suggests that wisdom can be more readily found among financially and underprivileged persons with low perceived social support, such as members of minority groups, the elderly, women, and individuals that are illiterate (Brugman, 2000). Brugman (2000) also indicated that those with fewer resources in terms of finding satisfaction and happiness in the external environment are more inclined towards self-understanding, which can be considered one of the requirements for the achievement of wisdom. It can be assumed then that wisdom will exert a positive effect on a person's life satisfaction.

\section{Having a "big picture" perspective}

Perspective, according to one view, means the ability to see "the bigger picture" in life, and concerns being able to see "the forest and the trees" and avoid becoming overly concerned about the small details in our lives when there are bigger things to think about. When you are talking with someone for example, perspective helps you think about the lessons you have learned in life and what is best for a particular situation. This ability to look at "the big picture" helps you to offer good advice to others, and those that have a good perspective on life seem to have a strong sense of selfknowledge and understand their limitations.

Niemiec and McGrath (2019) suggested that the ability to think in terms of big issues, such as death and one's role in the world, is more strongly and deeply connected with the well-being of older people than are such conditions as physical health, socioeconomic status, their financial situation, and physical and social environments. Furthermore, perspective helps to protect one against the negative effects of stress and trauma. Thus, it is hypothesized here that a "big picture" perspective is positively related to a person's life satisfaction.

\section{Self-awareness}

Self-awareness means being aware of your thoughts and feelings as they come to your consciousness, but without becoming too attached to them. This can help one remain calm and can reduce stress, and can help a person think clearly and better cope with difficult situations. Further, it can also improve one's moods, which can be considered our general feelings and thoughts as we pass in and out of positive and negative thoughts and feelings in different circumstances. Self-awareness can additionally reduce our experience of worrying about the events that we encounter in our lives, and our feeling of anxiety and depression. Many studies have discussed the fact that thinking about the past too much and worrying about the future are strongly connected with our feelings of anxiety and depression (Michel et al., 2013). Although it can be considered that stress is a "natural" part of living, many authors have suggested that if we are able to better focus on "living in the moment" we can reduce our negative thoughts and feelings and retain a relatively good level of calm, which of course is closely tied with our mental health and sense of well-being. In fact, heightening our awareness of our present thoughts and feelings has been shown to enhance our well-being for years (Huppert, 2009). Self-awareness can be considered the development of a better connection with ourselves, becoming more aware of our needs, values, and interests and the behaviors that are consistent with them. Self-determination theory is based to a large degree on this idea-the ability to control our behaviors for our better sense of well-being and mental health (New Economics Foundation, 2008). Therefore, it is assumed that being self-aware is likely to lead to one's life satisfaction. 


\section{Honesty}

According to Smith (2003, p. 518), an honest person is one that refuses to pretend that facts are other than what they are and remarked that we need to have truthful information from others, especially if we are to arrive at accurate beliefs about ourselves. From this point of view, dishonesty or lying to others-that is, providing false information or distorting information (Braginsky, 1970)can result in people not being able "to see facts related to the self as they are" (self-honesty). As a result, without a basis of truthful facts the person will tend to think, feel, and act with false impressions, and if these impressions are falsely positive, the individual may develop an incorrect view of his or her well-being. Moreover, dishonesty can also have direct effects on the person that is dishonest, such as possession negative emotions such as shame, fear of discovery, and unhappiness (e.g. Lewis and Saarni, 1993; Ten, Brinke and Porter, 2012). Thus, it can be seen that honesty contributes to a realistic evaluation of one's self and can have a strong influence on the person that is dishonest and on the person that bears the brunt of the person's dishonesty. In fact it can be stated that honesty is a necessary element of growth (Dewey, 1933) and is a basis for changing unhealthy thoughts and behaviors, which can strongly impede genuine happiness. Thus, it is hypothesized that honesty will have a positive effect on one's life satisfaction.

\section{Kindness}

Practicing kindness towards others can be seen to positively affect not only the person who is being kind but also the person that is the recipient of the kindness. Dew and Wilcox (2013) have argued that kindness and generosity towards one's spouse for example has a significant effect on the quality of the relationship, and Bardi and Buchanan (2010) found that performing acts of kindness towards others can improve one's personal sense of well-being. In their study, the participants were randomly assigned to perform either 1) no kind acts, 2) kind acts, or 3) new forms of kind acts each day for ten days, and it was revealed that those that performed kind acts demonstrated an increase in their sense of being satisfied with their lives. On the other hand, the participants that performed new forms of kind acts demonstrated great increases in their life satisfaction. The study showed that people tend to become happier when they are engaged in a variety of kind acts. In addition to this, Otake et al. (2006) conducted a study that demonstrated how performing kind acts can increase one's happiness. In their study, they also explored how "counting" and/or reflecting on one's kind acts can have an influence on one's emotional well-being. In the study, the participants became involved in acts that were considered to be kind for a week. Some of the participants were asked to count their kind acts, while the remaining participants were not asked to do so. Overall, the study found that those that actively counted their good acts were significantly happier than the participants that did not engage in the counting process. This leads to the conclusion that while performing kind acts increases one's subjective well-being, reflecting on and recording those acts can accelerate this improvement. Therefore, it can be hypothesized that kindness is positively related to a person's life satisfaction.

\section{Social intelligence}

Thorndike proposed the concept of social intelligence in the early part of the twentieth century. As Asgari and Roshani (2012) have suggested, social intelligence is the ability to understand others and to behave intelligently while interacting with them, and to use this intelligence to maintain adaptive social interactions. Another view of social intelligence was offered by Nijholt et al. (2009) as a skill that is essential for people to communicate and interact effectively with others and to understand them. In the words of Sells (2007), social intelligence can be widely viewed as a requirement for behavior and interactions. Moreover, Crowne (2009) defined social intelligence as the potential for an individual to display behavior that is appropriate in terms of achieving specific goals. In fact, social intelligence is not about knowing about how to act but concerns the ability to actually act intelligently in social circumstances. It can be seen then that, social intelligence is multifaceted and includes numerous skills and social qualifications that influence an individual's ability to identify, understand, and manage his or her emotions. It also provides a framework for the individual to face challenges and to solve a variety of problems, such as those concerning health and adjustment to society (Safavi et al., 2009). Zirkel (2000) believes that social intelligence is closely connected with a person's personality and his or her behavior, and some studies have also indicated that social intelligence and effective communication are required for success in one's life, work, and education (Garmaroodi and Vahdaninia, 2006). Naeifar and Behzadmoghaddam (2016) found a significant relationship between perceived social support and a person's life satisfaction, and Animasahun (2010) found significant relationships among social intelligence, the individual's ability to make adjustments to life, and the life satisfaction of university students. Therefore, it can be hypothesized that social intelligence positively correlates with life satisfaction. 


\section{Intangible values}

Numerous studies have demonstrated that "buying and consuming" life experiences (for example purchasing a tour package for travelling), instead of material items, leads to a person's greater sense of well-being (Caprariello and Reis, 2013; Dunn et al., 2011; Howell and Hill, 2009; Nicolao et al., 2009; Pchelin and Howell, 2014; Van Boven and Gilovich, 2003). Why is this the case? Lyubomirsky and Layous (2013) suggested that any activity can make people happier if it leads to positive emotions, thoughts, and behaviors, or if it satisfies one's need for autonomy, competence, and relatedness (see also Deci and Ryan, 2012). The need for autonomy, it has been suggested, is satisfied by experiencing behaviors that express our true identity and that bring about a feeling of being in charge of our actions (Ryan and Deci, 2000). One needs to experience the feeling of competence; on the other hand, satisfaction can be gained through engaging in activities that utilize our skills and abilities (Deci, 1975). Further, the need for having a sense of relatedness is satisfied by being engaged in activities that lead to a sense of belongingness in social situations (Baumeister and Leary, 1995). Indeed, past research has theorized and demonstrated that one reason that "consuming" life experiences rather than material items leads to a greater sense of well-being is because of our satisfaction from relatedness and identity needs (i.e., a proxy for autonomy in the material-experiential buying literature) (Carter and Gilovich, 2012; Howell and Hill, 2009; Howell and Howell, 2008). For example, life experiences compared to purchasing material items are more likely to be shared with others and this will lead to greater feelings of relatedness (Caprariello and Reis, 2013; Raghunathan and Corfman, 2006). In fact, many of our life experiences are "purchased" with the intention of developing or having a sense of connection with others or belonging to a particular community (Arnould and Price, 1993; Cotte, 1997). Additionally, life experiences, compared to the purchase of material items, comprise a better representation of our "true" selves (Carter and Gilovich, 2012). This means that people tend to define themselves more in terms of their life experiences than the material items that they possess. In fact, certain life experiences, such as mountain climbing or surfing, are carried out with the intention to help construct our identity and to express ourselves (Celsi, Rose and Leigh, 1993). In short, intangible values such as life experience can be positively related to life satisfaction.

\section{Gift giving}

Dunn et al. (2008) used an experimental design to test the claim that spending money on others leads to greater happiness levels than spending money on oneself. Their hypothesis was that the individuals that were randomly assigned to spend money in a pro-social fashion would be happier in the end than others that were assigned to spend money on themselves. The participants were approached in person during the morning hours in public places and were asked to report their baseline level of happiness. After doing so, they were randomly assigned to one of four spending conditions, receiving either five or twenty dollars to spend on themselves or others. Specifically, the participants in the personal spending category were asked to use their windfall on a bill, expense or gift for themselves, while the participants in the pro-social spending group were asked to spend the money on a gift for someone or to make a donation to charity. All of the participants were asked to spend the money according to their assigned spending instructions by $5 \mathrm{pm}$ that day, and they were then contacted in the evening hours (between $6 \mathrm{pm}$ and $8 \mathrm{pm}$ ) by phone by a research assistant in order to complete the follow-up survey, which assessed their current happiness level. As predicted, the participants asked to spend their money in a pro-social way were happier than were the participants that spent their money in a personal way. It is interesting that the amount of money that the people were given did not influence how happy they were that evening, and this suggests that how the people spent their money was more important than how much money they received. Therefore, this study provides support for the claim that spending money on others leads to greater happiness than spending money on oneself. Moreover, the results suggest that it is not necessary for the amount of money to be large for it to lead to positive outcomes since the pro-social purchases made with as little as five dollars were sufficient to increase the participants' levels of happiness. Thus, it is assumed that spending money on others through gift giving tends to create happiness or life satisfaction.

\section{Social responsibility}

Research into pro-social behaviors suggests that responsible behavior is important for a number of reasons. Community service and volunteer work have been found to contribute to subjective well-being through increased self-esteem, greater life satisfaction, and a greater sense of control (c.f. Thoits and Hewitt, 2001). According to Ryan and Deci (2001), when people engage with others responsibly and at the same time experience success, they begin to appreciate their own skills and ability to effect changes, and this in turn can increase their self-confidence and create a sense of competence, thus satisfying important psychological and social needs (Ryan and Deci, 2001). 
Furthermore, in a study of pioneer researchers in the lifestyle field, Degenhardt (2002) found that taking responsibility for one's behaviour is closely connected with the desire to find meaning in one's life-finding a purpose in life is important in terms of contributing to one's subjective well-being since it creates a sense of giving one's self tasks that he or she deems significant. However, culture can be seen to play a role here, since the extent to which taking responsibility helps one to find purpose or meaning in life depends upon cultural values and what is considered to be important in the society in which the person lives. Similarly, WeD research found that living a good and honest life was extremely important to people (Camfield, 2006); this sense of morality is fundamentally connected with one's relationships, and living responsibly with others and with the environment is important for contributing to this sense of "feeling right." Therefore, it can be hypothesized that social responsibility is likely to relate to life satisfaction positively.

\section{Hope}

Hope is one of the characteristics that all of us possess, from the time we are little to the time of our old age. It has been placed in the category of positive psychology-Snyder and Lopez (2005) have treated hope as a cognitive-focused member of the positive psychology family. Hope has been conceptualized according to two interrelated pathways (the perceived capacity to generate successful avenues to one's desired goal) and agency cognitions (the perceived motivation to use these pathways) (Snyder, 2002; Snyder et al., 1991; Snyder, Irving and Anderson, 1991). Similarly, researchers have reported that hope is negatively correlated with depression (Chang and DeSimone, 2001; Chang, 2003; Kwon, 2000; O’Sullivan, 2011; Peterson and Seligman, 2004) and positively connected with life satisfaction (Bailey and Snyder, 2010; Chang, 1998, 2003; Gilman, Dooley and Florell, 2006). Studies have argued that high hopes results in diminished stress and greater effective emotional recovery of individuals (Ong, Edwards and Bergeman, 2006). Hope has also been seen to function significantly in the mitigation of the effect of depression in the elderly (Hirsch, Sirois and Lyness, 2011). These individuals for example show less depressive symptoms and a lower degree of functional impairment compared to those that live with greater hope, and therefore these individuals tend to be comparatively happier than others. Further, Valle, Huebner, and Suldo (2004) found that hope demonstrates a positive correlation with the general life satisfaction of adolescents and is inversely correlated with internalizing and externalizing behaviors. It can be assumed then that hope has a positive influence on a person's life satisfaction.

\section{Humor}

Peterson and Seligman (2004), in developing a model for a person's positive personal strengths rather than pathologies, proposed a set of virtues based on the presence of different strengths of character. They identified 24 character strengths in support of six virtues-these character strengths and virtues were assumed to influence how satisfied and fulfilled individuals feel about their lives. Humor was included in their list as one of the character strengths that helped to support the virtue of what they called transcendence. In their model, transcendence represents those strengths that allow a person to find meaning and to feel connected to the wider world. As a character strength, humor was defined as liking to joke and laugh and sharing humor with others. For Peterson and Seligman (2004), higher levels of character strengths were assumed to be connected with greater life satisfaction, and in two studies involving large samples in three countries, humor, assessed as a character strength, was seen to be positively related to life satisfaction and other indicators of wellbeing (Peterson, Ruch, Beermann, Park and Seligman, 2007; Ruch et al., 2010). Thus, it appears that a good sense of humor can provide the basis for a positive worldview and greater personal strength, thus leading to a person's sense of well-being and life satisfaction.

\section{Methods}

\section{Survey}

The questionnaire used in the present study was first pretested with a group of 25 MBA students. Then, personal interviews were conducted with twenty-five randomly-sampled adults that were at least 18 years of age. The questionnaire was assessed for its suitability, readability, and for possible ambiguity, and it was revised based on the feedback received from both groups. Then, four hundred and ninety-eight eligible respondents were interviewed in fifty department stores and discount stores spread over the Bangkok area. The response rate was $66 \%$.

\section{Data Analysis}

Generally speaking, the character strengths of individuals are likely to have a positive impact on their life satisfaction, particularly as indicated previously in terms of curiosity, love of learning, wisdom, having a "big picture" perspective, self-awareness, honesty, kindness, social intelligence, 
intangible values, gift giving, social responsibility, and hope and humor. In order to investigate whether this hypothesis was true, a regression analysis was conducted for the present study. Specifically, the earlier-mentioned independent variables, as well as the demographic characteristics, including gender, age, marital status, education, and monthly household income, which were also used as the independent variables because they were used as the control variables, were regressed on life satisfaction, which was used as the dependent variable.

Life satisfaction was measured using the Cantril ladder, where people were asked to place their lives on a ladder with ten rungs, with the top (tenth) rung being the best possible life and the bottom rung being the worst. In addition, all of the independent variables were measured by asking the respondents to evaluate the extent of their character strengths. The level of these character strengths ranged from 1 , meaning very little, to 10 , meaning very much. It should be noted that education was divided into low education, consisting of people with lower than a bachelor's degree, and high education, consisting of those with at least a bachelor's degree. Household income was also divided into two groups: the low household income group was comprised of persons that earned less than 70,000 baht/month, whereas the high household income group was comprised of those that earned at least 70,000 baht/month.

\section{Results and discussion}

The results of the multiple regression analysis are shown in Table 1.

\begin{tabular}{|c|c|c|c|c|c|c|c|}
\hline \multirow[t]{2}{*}{ Model } & \multicolumn{2}{|c|}{$\begin{array}{l}\text { Unstandardized } \\
\text { Coefficients }\end{array}$} & \multirow{2}{*}{$\begin{array}{c}\begin{array}{c}\text { Standardized } \\
\text { Coefficients }\end{array} \\
\text { Beta } \\
\end{array}$} & \multirow[t]{2}{*}{$\mathbf{t}$} & \multirow[t]{2}{*}{ Sig. } & \multicolumn{2}{|c|}{$\begin{array}{c}\text { Collinearity } \\
\text { Statistics }\end{array}$} \\
\hline & B & Std. Error & & & & Tolerance & VIF \\
\hline (Constant) & 2.383 & .748 & & 3.186 & $.002 *$ & & \\
\hline Curiosity & -.066 & .039 & -.085 & -1.698 & $.090^{*}$ & .654 & 1.529 \\
\hline Love of Learning & -.062 & .053 & -.068 & -1.169 & .243 & .487 & 2.053 \\
\hline Wisdom & .264 & .059 & .257 & 4.440 & $.000^{*}$ & .495 & 2.020 \\
\hline Big Picture & .049 & .046 & .052 & 1.066 & .287 & .707 & 1.414 \\
\hline Self-Awareness & .142 & .050 & .146 & 2.869 & $.004^{*}$ & .640 & 1.562 \\
\hline Honesty & .007 & .064 & .006 & .114 & .909 & .537 & 1.863 \\
\hline Kindness & -.012 & .059 & -.011 & -.204 & .838 & .554 & 1.806 \\
\hline Social Intelligence & -.007 & .046 & -.008 & -.155 & .877 & .647 & 1.545 \\
\hline Intangible Values & .073 & .034 & .098 & 2.125 & $.034^{*}$ & .776 & 1.288 \\
\hline Gift Giving & -.039 & .040 & -.051 & -.970 & .333 & .611 & 1.637 \\
\hline \begin{tabular}{|l|} 
Social \\
Responsibility \\
\end{tabular} & .100 & .056 & .099 & 1.777 & $.076^{*}$ & .538 & 1.857 \\
\hline Hope & .119 & .048 & .125 & 2.481 & $.013^{*}$ & .649 & 1.541 \\
\hline Humor & -.039 & .048 & -.042 & -.825 & .410 & .652 & 1.533 \\
\hline Gender & .083 & .126 & .028 & .660 & .509 & .929 & 1.077 \\
\hline Age & -.002 & .007 & -.013 & -.220 & .826 & .505 & 1.980 \\
\hline Marrygroup & -.277 & .173 & -.087 & -1.602 & .110 & .559 & 1.788 \\
\hline Educgroup & .362 & .152 & .108 & 2.377 & $.018^{*}$ & .809 & 1.237 \\
\hline Incgroup & .400 & .134 & .134 & 2.980 & $.003^{*}$ & .821 & 1.218 \\
\hline
\end{tabular}

Taken together, the 18 independent variables accounted for $27 \%$ of the variance in life satisfaction (R-squared $=.270$ ). It should also be noted that multicollinearity was not a likely problem because the magnitude of the variance inflation factors associated with each independent variable was far less than ten (Wetherill et al., 1986). According to the standardized beta coefficients, the variables that had the greatest positive impact to the least positive impact on life satisfaction were wisdom, self-awareness, household income, hope, education, social responsibility, and intangible values. It is noteworthy that social responsibility and intangible values were approximately equally important. Surprisingly, the only variable that had a negative impact on life satisfaction was curiosity. This may be because the more curious people are, the more they realize that they do not know a lot of things. It should also be pointed out that the variables that had to do with self, namely wisdom, self-awareness, household income, and hope and education tended to have more positive influences on people's life satisfaction than the variable that had to do with others (i.e., social responsibility) as well as how wisely people spent their money on experience rather than material items (i.e., intangible values). Household income was found to be a significant determinant of people's life satisfaction. Understandably, the high household income group was more satisfied with their lives than the low household income group. It was considered interesting to find out, through further investigation, 
how character strengths affect the life satisfaction of people in varying household income segments. Toward this end, two similar multiple regressions for the whole sample were run. One was for the low household income segment and the other was for the high household income segment. The results of the multiple regression for the low household income segment, as shown in Table 2, revealed that wisdom had the most positive impact on people's life satisfaction, followed by selfawareness and hope. Similar to the entire population, curiosity had a negative impact on people's life satisfaction. It should be noted that all of the character strengths that had an impact on people's life satisfaction were self-related.

Table 2: Results of the multiple regression for life satisfaction on human character strengths in the low household income group

\begin{tabular}{|c|c|c|c|c|c|c|c|}
\hline \multirow[t]{2}{*}{ Model } & \multicolumn{2}{|c|}{$\begin{array}{l}\text { Unstandardized } \\
\text { Coefficients }\end{array}$} & \multirow{2}{*}{$\begin{array}{c}\begin{array}{c}\text { Standardized } \\
\text { Coefficients }\end{array} \\
\text { Beta } \\
\end{array}$} & \multirow[t]{2}{*}{$\mathbf{t}$} & \multirow[t]{2}{*}{ Sig. } & \multicolumn{2}{|c|}{$\begin{array}{l}\text { Collinearity } \\
\text { Statistics }\end{array}$} \\
\hline & B & Std. Error & & & & Tolerance & VIF \\
\hline (Constant) & 3.721 & 1.160 & & 3.208 & $.002 *$ & & \\
\hline Curiosity & -.120 & .056 & -.158 & -2.130 & $.034 *$ & .691 & 1.447 \\
\hline Love of Learning & -.118 & .088 & -.124 & -1.336 & .183 & .440 & 2.272 \\
\hline Wisdom & .382 & .105 & .354 & 3.639 & $.000 *$ & .401 & 2.493 \\
\hline Big Picture & .054 & .075 & .053 & .716 & .475 & .700 & 1.429 \\
\hline Self-Awareness & .171 & .081 & .168 & 2.122 & $.035 *$ & .605 & 1.654 \\
\hline Honesty & .006 & .117 & .005 & .052 & .958 & .431 & 2.319 \\
\hline Kindness & -.095 & .112 & -.078 & -.848 & .398 & .448 & 2.231 \\
\hline Social Intelligence & .035 & .079 & .036 & .438 & .662 & .552 & 1.812 \\
\hline Intangible Values & .083 & .055 & .108 & 1.509 & .133 & .746 & 1.341 \\
\hline Gift Giving & -.043 & .065 & -.053 & -.668 & .505 & .592 & 1.689 \\
\hline $\begin{array}{l}\text { Social } \\
\text { Responsibility }\end{array}$ & .023 & .094 & .022 & .239 & .811 & .467 & 2.143 \\
\hline Hope & .152 & .081 & .153 & 1.888 & $.060^{*}$ & .575 & 1.739 \\
\hline Humor & -.045 & .080 & -.046 & -.561 & .575 & .555 & 1.802 \\
\hline Gender & -.009 & .206 & -.003 & -.046 & .963 & .944 & 1.059 \\
\hline Age & -.010 & .012 & -.070 & -.866 & .388 & .574 & 1.741 \\
\hline Marrygroup & -.349 & .275 & -.101 & -1.272 & .205 & .606 & 1.651 \\
\hline Educgroup & .359 & .224 & .109 & 1.599 & .112 & .820 & 1.219 \\
\hline
\end{tabular}

The results of the multiple regressions for the high household income segment, as shown in Table 3, indicated that wisdom, social responsibility, hope, and education had positive impacts on people's life satisfaction, whereas wisdom had the greatest impact on life satisfaction. Similar to the low-household income group, the high-household income group was influenced the most by wisdom. However, according to the t-test, the mean difference of wisdom for the low-household income group and the high household group was not significant. This means that the character strength of wisdom was the same across the two household income groups. In other words, people were not wiser because they were at a higher household income level.

Additionally, education was found to be another significant determinant of people's life satisfaction. Understandably, the high education group was more satisfied with their lives than the low education group. It was also considered to be interesting to find out, through further investigation, how character strengths affect life satisfaction of people in varying education segments. Toward this end, two other similar multiple regressions for the whole sample were run. One was for the low education segment and the other was for the high education segment.

The results of the multiple regressions for the low education segment, as shown in Table 4, revealed that wisdom and intangible values had positive impacts on people's life satisfaction, whereas wisdom was more influential than intangible values. It should be noted that even those that attained less than a bachelor degree level relied on wisdom in order to be happy the most, followed by their ways of making use of their money wisely by spending on experiential things more than material items. 
Table 3: Results of the multiple regressions for life satisfaction on human character strengths in the high household income group

\begin{tabular}{|c|c|c|c|c|c|c|c|}
\hline \multirow[t]{2}{*}{ Model } & \multicolumn{2}{|c|}{$\begin{array}{l}\text { Unstandardized } \\
\text { Coefficients }\end{array}$} & \multirow{2}{*}{$\begin{array}{c}\begin{array}{c}\text { Standardized } \\
\text { Coefficients }\end{array} \\
\text { Beta }\end{array}$} & \multirow[t]{2}{*}{$\mathbf{t}$} & \multirow[t]{2}{*}{ Sig. } & \multicolumn{2}{|c|}{$\begin{array}{c}\text { Collinearity } \\
\text { Statistics }\end{array}$} \\
\hline & B & Std. Error & & & & Tolerance & VIF \\
\hline (Constant) & 2.262 & .984 & & 2.298 & $.022 *$ & & \\
\hline Curiosity & .004 & .055 & .005 & .071 & .943 & .634 & 1.577 \\
\hline Love of Learning & -.073 & .067 & -.088 & -1.089 & .277 & .485 & 2.061 \\
\hline Wisdom & .190 & .071 & .203 & 2.675 & $.008^{*}$ & .548 & 1.823 \\
\hline Big Picture & .054 & .059 & .062 & .918 & .360 & .695 & 1.439 \\
\hline Self-Awareness & .090 & .064 & .101 & 1.417 & .158 & .624 & 1.602 \\
\hline Honesty & $-2.861 \mathrm{E}-5$ & .077 & .000 & .000 & 1.000 & .563 & 1.777 \\
\hline Kindness & .041 & .067 & .044 & .620 & .536 & .623 & 1.606 \\
\hline Social Intelligence & -.029 & .058 & -.034 & -.493 & .623 & .658 & 1.519 \\
\hline Intangible Values & .054 & .046 & .078 & 1.184 & .238 & .724 & 1.382 \\
\hline Gift Giving & -.023 & .052 & -.033 & -.445 & .656 & .582 & 1.718 \\
\hline $\begin{array}{l}\text { Social } \\
\text { Responsibility }\end{array}$ & .157 & .070 & .167 & 2.248 & $.026^{*}$ & .569 & 1.756 \\
\hline Hope & .145 & .060 & .166 & 2.411 & $.017^{*}$ & .665 & 1.503 \\
\hline Humor & -.046 & .061 & -.052 & -.755 & .451 & .667 & 1.498 \\
\hline Gender & .114 & .159 & .043 & .714 & .476 & .858 & 1.165 \\
\hline Age & .006 & .009 & .062 & .694 & .488 & .401 & 2.493 \\
\hline Marrygroup & -.128 & .228 & -.046 & -.562 & .575 & .473 & 2.114 \\
\hline Educgroup & .409 & .220 & .109 & 1.856 & $.065^{*}$ & .913 & 1.095 \\
\hline
\end{tabular}

\begin{tabular}{|c|c|c|c|c|c|c|c|}
\hline \multirow[t]{2}{*}{ Model } & \multicolumn{2}{|c|}{$\begin{array}{l}\text { Unstandardized } \\
\text { Coefficients }\end{array}$} & \multirow{2}{*}{$\begin{array}{c}\begin{array}{c}\text { Standardized } \\
\text { Coefficients }\end{array} \\
\text { Beta }\end{array}$} & \multirow[t]{2}{*}{ t } & \multirow[t]{2}{*}{ Sig. } & \multicolumn{2}{|c|}{$\begin{array}{c}\text { Collinearity } \\
\text { Statistics }\end{array}$} \\
\hline & B & Std. Error & & & & Tolerance & VIF \\
\hline (Constant) & 5.274 & 1.802 & & 2.927 & $.004^{*}$ & & \\
\hline Curiosity & -.082 & .077 & -.104 & -1.062 & .291 & .667 & 1.500 \\
\hline Love of Learning & -.188 & .116 & -.185 & -1.626 & .107 & .494 & 2.024 \\
\hline Wisdom & .436 & .124 & .425 & 3.526 & $.001^{*}$ & .440 & 2.271 \\
\hline Big Picture & .120 & .094 & .122 & 1.270 & .207 & .697 & 1.434 \\
\hline Self-Awareness & .152 & .106 & .159 & 1.437 & .154 & .524 & 1.907 \\
\hline Honesty & .091 & .148 & .072 & .616 & .539 & .466 & 2.145 \\
\hline Kindness & -.195 & .140 & -.169 & -1.395 & .166 & .437 & 2.287 \\
\hline Social Intelligence & -.003 & .102 & -.003 & -.032 & .975 & .600 & 1.666 \\
\hline Intangible Values & .130 & .077 & .166 & 1.696 & $.093^{*}$ & .667 & 1.498 \\
\hline Gift Giving & .014 & .094 & .017 & .150 & .881 & .470 & 2.128 \\
\hline $\begin{array}{l}\text { Social } \\
\text { Responsibility }\end{array}$ & .012 & .133 & .012 & .093 & .926 & .403 & 2.482 \\
\hline Hope & -.052 & .104 & -.049 & -.500 & .618 & .680 & 1.470 \\
\hline Humor & -.037 & .103 & -.038 & -.355 & .723 & .556 & 1.798 \\
\hline Gender & .047 & .293 & .014 & .159 & .874 & .847 & 1.180 \\
\hline Age & -.016 & .014 & -.124 & -1.141 & .256 & .540 & 1.852 \\
\hline Marrygroup & -.552 & .372 & -.159 & -1.484 & .141 & .558 & 1.791 \\
\hline Incgroup & .256 & .325 & .068 & .787 & .433 & .849 & 1.178 \\
\hline
\end{tabular}

The results of the multiple regressions for the high education segment, as shown in Table 5, indicated that hope had the greatest positive impacts on people's life satisfaction, followed by wisdom, household income, social responsibility, and self-awareness. Similar to the low education group, wisdom was the character strength that made the high education group happy as well. According to the t-test, the mean difference in the wisdom of these two groups was significant. Specifically, the mean value of the wisdom of the low education group was 6.80, whereas for the high education group it was 7.49. This means that people whose education was at least at the bachelor degree level thought that they were more intelligent in making use of their knowledge than those with a lower level of education. This may be because throughout the process of education, people have the chance to apply the knowledge that they have learned as a part of their intellectual exercises. 
Table 5. Results of the Multiple Regressions for Life Satisfaction on Human Character

Strengths in the High Education Group

\begin{tabular}{|c|c|c|c|c|c|c|c|}
\hline \multirow[t]{2}{*}{ Model } & \multicolumn{2}{|c|}{$\begin{array}{l}\text { Unstandardized } \\
\text { Coefficients }\end{array}$} & \multirow{2}{*}{$\begin{array}{c}\begin{array}{c}\text { Standardized } \\
\text { Coefficients }\end{array} \\
\text { Beta }\end{array}$} & \multirow[t]{2}{*}{$\mathbf{t}$} & \multirow[t]{2}{*}{ Sig. } & \multicolumn{2}{|c|}{$\begin{array}{l}\text { Collinearity } \\
\text { Statistics }\end{array}$} \\
\hline & B & Std. Error & & & & Tolerance & VIF \\
\hline (Constant) & 2.108 & .837 & & 2.519 & $.012^{*}$ & & \\
\hline Curiosity & -.042 & .046 & -.056 & -.919 & .359 & .637 & 1.569 \\
\hline Love of Learning & -.035 & .061 & -.042 & -.583 & .560 & .456 & 2.194 \\
\hline Wisdom & .200 & .069 & .195 & 2.909 & $.004^{*}$ & .516 & 1.937 \\
\hline Big Picture & -.005 & .054 & -.006 & -.100 & .920 & .712 & 1.404 \\
\hline Self-Awareness & .119 & .057 & .125 & 2.097 & $.037^{*}$ & .657 & 1.522 \\
\hline Honesty & -.027 & .072 & -.025 & -.379 & .705 & .520 & 1.922 \\
\hline Kindness & .046 & .064 & .045 & .714 & .475 & .595 & 1.682 \\
\hline Social Intelligence & .006 & .052 & .008 & .125 & .901 & .627 & 1.595 \\
\hline Intangible Values & .021 & .039 & .029 & .533 & .594 & .769 & 1.300 \\
\hline Gift Giving & -.029 & .044 & -.041 & -.664 & .507 & .621 & 1.610 \\
\hline $\begin{array}{l}\text { Social } \\
\text { Responsibility }\end{array}$ & .123 & .062 & .128 & 1.976 & $.049 *$ & .554 & 1.804 \\
\hline Hope & .188 & .054 & .216 & 3.513 & $.001^{*}$ & .617 & 1.622 \\
\hline Humor & -.024 & .054 & -.026 & -.440 & .660 & .646 & 1.549 \\
\hline Gender & .035 & .140 & .013 & .248 & .804 & .890 & 1.123 \\
\hline Age & .011 & .008 & .099 & 1.386 & .167 & .459 & 2.178 \\
\hline Marrygroup & -.027 & .199 & -.009 & -.138 & .891 & .515 & 1.943 \\
\hline Incgroup & .435 & .143 & .154 & 3.054 & $.002^{*}$ & .911 & 1.098 \\
\hline
\end{tabular}

It should be pointed out that wisdom was the only character strength that consistently determined life satisfaction regardless of the household income or education level. In order to obtain this character strength, education seemed to be a good strategy, not household income. Since education can be a source of household income, it may generate additional happiness through incremental household income as well. Therefore, to aim at happiness as an end, education is likely to be a good means.

\section{Conclusion}

According to the present writing, the character strengths, as well as the demographic characteristics that had positive impacts on life satisfaction for the overall population, were wisdom, self-awareness, household income, hope, education, social responsibility, and intangible values. The only negative element regarding life satisfaction was curiosity. Further analysis of the low household income segment revealed that wisdom, self-awareness, and hope were key positive determinants of life satisfaction, whereas curiosity was the sole negative driver of life satisfaction. For the high household income segment, the positive determinants of life satisfaction were wisdom, social responsibility, hope, and education. The detailed analysis of the low education group indicated that the only two positive influencers on life satisfaction were wisdom and intangible values. In addition, the analysis of the high education group suggested that the positive drivers of life satisfaction were hope, wisdom, household income, social responsibility, and self-awareness. It should be noted that the sole human character strength that had a positive influence on life satisfaction in the entire population and across the population subgroups of varying household income and education was wisdom, which can be gained through education but not through household income.

\section{Funding}

The author(s) received no financial support for the research, authorship, and/or publication of this article.

\section{Declaration of conflicting interests}

The author(s) declared no potential conflicts of interest with respect to the research, authorship, and/or publication of this article. 


\section{Citation information}

Leelakulthanit, 0. (2021). The influence of human character strengths on life satisfaction. Economics, Management and Sustainability, 6(2), 46-59. doi:10.14254/jems.2021.6-2.4

\section{Reference}

Animasahun, R. A. (2010). Intelligent quotient, emotional intelligence and spiritual intelligence as correlates of prison adjustment among inmates in Nigeria prisons. Journal of Social sciences, 22(2), 121-128.

Ardelt, M. (2000). Antecedents and effects of wisdom in old age: A longitudinal perspective on aging well. Research on aging, 22(4), 360-394.

Arnould, E. J., \& Price, L. L. (1993). River magic: Extraordinary experience and the extended service encounter. Journal of consumer Research, 20(1), 24-45.

Asgari, P., \& Roshani, K. (2012). The comparison of cultural intelligence, Emotional intelligence, personal-social adjustment in male and female students of Ahwaz Islamic Azad University. Journal of woman and culture, 3(12), 49-63.

Bailey, T. C., \& Snyder, C. R. (2007). Satisfaction with life and hope: A look at age and marital status. The Psychological Record, 57(2), 233-240.

Baltes, P. B., Staudinger, U. M., Maercker, A., \& Smith, J. (1995). People nominated as wise: A comparative study of wisdom-related knowledge. Psychology and aging, 10(2), 155.

Baumeister, R. F., \& Leary, M. R. (1995). The need to belong: desire for interpersonal attachments as a fundamental human motivation. Psychological bulletin, 117(3), 497-529.

Ben-Zur, H. (2002). Associations of Type A behavior with the emotional traits of anger and curiosity. Anxiety, Stress \& Coping, 15(1), 95-104.

Berlyne, D. E. (1960). Conflict, arousal, and curiosity. New York: McGraw-Hill.

Boyle, G. J. (1983). Critical review of state-trait curiosity test development. Motivation and Emotion, 7(4), 377-397.

Braginsky, D. D. (1970). Machiavellianism and manipulative interpersonal behavior in children. Journal of experimental Social psychology, 6(1), 77-99.

Brugman, G. (2000). Wisdom: Source of Narrative Coherence \& Eudaimonia: A Life-span Perspective. Eburon.

Buchanan, K. E., \& Bardi, A. (2010). Acts of kindness and acts of novelty affect life satisfaction. The Journal of social psychology, 150(3), 235-237.

Camfield, L. (2006). Why and How of Understanding 'Subjective'Well-being: Exploratory work by the WeD group in four developing countries. [online] Available at: <http://www. bath.ac.uk/socpol/welldev/research/workingpaperpdf/wed26. pdf> [Access 1 February 2020].

Caprariello, P. A., \& Reis, H. T. (2013). To do, to have, or to share? Valuing experiences over material possessions depends on the involvement of others. Journal of personality and social psychology, 104(2), 199-215.

Carter, T. J., \& Gilovich, T. (2012). I am what I do, not what I have: The differential centrality of experiential and material purchases to the self. Journal of personality and social psychology, 102(6), 1304-1317.

Celsi, R. L., Rose, R. L., \& Leigh, T. W. (1993). An exploration of high-risk leisure consumption through skydiving. Journal of consumer research, 20(1), 1-23.

Chang, E. C. (1998). Hope, problem-solving ability, and coping in a college student population: Some implications for theory and practice. Journal of clinical psychology, 54(7), 953-962.

Chang, E. C. (2003). A critical appraisal and extension of hope theory in middle-aged men and women: Is it important to distinguish agency and pathways components?. Journal of Social and Clinical Psychology, 22(2), 121-143.

Chang, E. C., \& DeSimone, S. L. (2001). The influence of hope on appraisals, coping, and dysphoria: A test of hope theory. Journal of social and clinical psychology, 20(2), 117-129. 
Clore, G. L., Ortony, A., \& Foss, M. A. (1987). The psychological foundations of the affective lexicon. Journal of personality and social psychology, 53(4), 751-766.

Cotte, J. (1997). Chances, trances, and lots of slots: Gambling motives and consumption experiences. Journal of Leisure Research, 29(4), 380-406.

Crowne, K. A. (2009). The relationships among social intelligence, emotional intelligence and cultural intelligence. Organization Management Journal, 6(3), 148-163.

Deci, E. L. (1975). Intrinsic motivation. New York and London. Plenum Press, 10, 978-1.

Deci, E. L., \& Ryan, R. M. (2012). Motivation, personality, and development within embedded social contexts: An overview of self-determination theory. In: R. M. Ryan, ed. 2012. The Oxford handbook of human motivation. New York: Oxford University Press, 85-107.

Degenhardt, L. (2002). Why do people act in sustainable ways? Results of an empirical survey of lifestyle pioneers. In Psychology of sustainable development (pp. 123-147). Springer, Boston, MA.

Depue, R. A., 1996. A neurobiological framework for the structure of personality and emotion: Implications for personality disorders. In: J. F. Clarkin and M. F. Lenzenweger, eds. 1996. Major theories of personality disorder. New York: Guilford Press, 347-90.

Dew, J., \& Bradford Wilcox, W. (2013). Generosity and the maintenance of marital quality. Journal of Marriage and Family, 75(5), 1218-1228.

Dewey, J. (1933). How we think: A restatement of the relation of reflective thinking to the educative process. DC Heath.

Dunn, E. W., Aknin, L. B., \& Norton, M. I. (2008). Spending money on others promotes happiness. Science, 319(5870), 1687-1688.

Dunn, E. W., Gilbert, D. T., \& Wilson, T. D. (2011). If money doesn't make you happy, then you probably aren't spending it right. Journal of Consumer Psychology, 21(2), 115-125.

Ferrari, M., Kahn, A., Benayon, M., \& Nero, J. (2011). Phronesis, sophia, and hochma: Developing wisdom in Islam and Judaism. Research in Human Development, 8(2), 128-148.

Frijda, N. H. (1994). Emotions are functional, most of the time. In: P. Ekman and R. J. Davidson, eds. The nature of emotion: Fundamental questions. New York: Oxford University Press, 112-22.

Garmaroudi, G. R., \& Vahdaninia, M. (2006). Social health: An investigation into social skills among students. Health Monitor Journal of the Iranian Institute for Health Sciences Research, 5(2), 141-47.

Gilman, R., Dooley, J., \& Florell, D. (2006). Relative levels of hope and their relationship with academic and psychological indicators among adolescents. Journal of Social and Clinical Psychology, 25(2), 166-178.

Hirsch, J. K., Sirois, F. M., \& Lyness, J. M. (2011). Functional impairment and depressive symptoms in older adults: Mitigating effects of hope. British Journal of Health Psychology, 16(4), 744-760.

Howell, R. T., \& Hill, G. (2009). The mediators of experiential purchases: Determining the impact of psychological needs satisfaction and social comparison. The Journal of Positive Psychology, 4(6), 511-522.

Howell, R. T., \& Howell, C. J. (2008). The relation of economic status to subjective well-being in developing countries: a meta-analysis. Psychological bulletin, 134(4), 536.

Huppert, F. A. (2009). Psychological well-being: Evidence regarding its causes and consequences. Applied psychology: health and well-being, 1(2), 137-164.

Jason, L. A., Reichler, A., King, C., Madsen, D., Camacho, J., \& Marchese, W. (2001). The measurement of wisdom: A preliminary effort. Journal of community psychology, 29(5), 585-598.

Jovanovic, V., \& Brdaric, D. (2012). Did curiosity kill the cat? Evidence from subjective well-being in adolescents. Personality and Individual Differences, 52(3), 380-384.

Kashdan, T. B., \& Steger, M. F. (2007). Curiosity and pathways to well-being and meaning in life: Traits, states, and everyday behaviors. Motivation and Emotion, 31(3), 159-173.

Kwon, P. (2000). Hope and dysphoria: The moderating role of defense mechanisms. Journal of Personality, 68(2), 199-223. 
Lewis, M., \& Saarni, C. (Eds.). (1993). Lying and deception in everyday life. Guilford press.

Lyubomirsky, S., \& Layous, K. (2013). How do simple positive activities increase well-being?. Current directions in psychological science, 22(1), 57-62.

Lyubomirsky, S., King, L., \& Diener, E. (2005). The benefits of frequent positive affect: Does happiness lead to success?. Psychological bulletin, 131(6), 803-855.

Michl, L. C., McLaughlin, K. A., Shepherd, K., \& Nolen-Hoeksema, S. (2013). Rumination as a mechanism linking stressful life events to symptoms of depression and anxiety: longitudinal evidence in early adolescents and adults. Journal of abnormal psychology, 122(2), 339-352.

New Economics Foundation, 2008. Five ways to wellbeing. [online] Available at: <https://b.3cdn.net/nefoundation/8984c5089d5c2285ee_t4m6bhqq5.pdf> [Access 2 February 2020].

Nicolao, L., Irwin, J. R., \& Goodman, J. K. (2009). Happiness for sale: Do experiential purchases make consumers happier than material purchases?. Journal of consumer research, 36(2), 188-198.

Niemiec, R. M., \& McGrath, R. E. (2019). The power of character strengths: Appreciate and ignite your positive personality. Cincinnati, $\mathrm{OH}$ : VIA Institute on Character.

Nijholt, A., Stock, O., \& Nishida, T. (2009). Social intelligence design in ambient intelligence. AI \& society, 24(1), 1-3.

O'Sullivan, G. (2011). The relationship between hope, eustress, self-efficacy, and life satisfaction among undergraduates. Social indicators research, 101(1), 155-172.

Ong, A. D., Edwards, L. M., \& Bergeman, C. S. (2006). Hope as a source of resilience in later adulthood. Personality and individual differences, 41(7), 1263-1273.

Otake, K., Shimai, S., Tanaka-Matsumi, J., Otsui, K., \& Fredrickson, B. L. (2006). Happy people become happier through kindness: A counting kindnesses intervention. Journal of happiness studies, 7(3), 361-375.

Park, N., Peterson, C., \& Seligman, M. E. (2004). Strengths of character and well-being. Journal of social and Clinical Psychology, 23(5), 603-619.

Park, N., Peterson, C., \& Sun, J. K. (2013). La psicología positiva: investigación y aplicaciones. Terapia psicológica, 31(1), 11-19.

Pchelin, P., \& Howell, R. T. (2014). The hidden cost of value-seeking: People do not accurately forecast the economic benefits of experiential purchases. The Journal of Positive Psychology, 9(4), 322334.

Perry, C. L., Komro, K. A., Jones, R. M., Munson, K., Williams, C. L., \& Jason, L. (2002). The measurement of wisdom and its relationship to adolescent substance use and problem behaviors. Journal of Child \& Adolescent Substance Abuse, 12(1), 45-63.

Seligman, M. E., Rashid, T., \& Parks, A. C. Peterson, C., \& Seligman, MEP (2004). Character strengths and virtues: A handbook and classification. Washington, DC: American Psychological Association and Oxford University Press. American Psychologist, 51, 1072-1079.

Peterson, C., Ruch, W., Beermann, U., Park, N., \& Seligman, M. E. (2007). Strengths of character, orientations to happiness, and life satisfaction. The journal of positive psychology, 2(3), 149156.

Raghunathan, R., \& Corfman, K. (2006). Is happiness shared doubled and sadness shared halved? Social influence on enjoyment of hedonic experiences. Journal of Marketing Research, 43(3), 386-394.

Ruch, W., Proyer, R. T., Harzer, C., Park, N., Peterson, C., \& Seligman, M. E. (2010). Values in Action Inventory of Strengths (VIA-IS). Journal of Individual Differences, 31(3), 138-149.

Ryan, R. M., \& Deci, E. L. (2000). Self-determination theory and the facilitation of intrinsic motivation, social development, and well-being. American psychologist, 55(1), 68-78.

Ryan, R. M., \& Deci, E. L. (2001). On happiness and human potentials: A review of research on hedonic and eudaimonic well-being. Annual review of psychology, 52(1), 141-166.

Safavi, M. A. H. B. O. U. B. E. H., SM, M. L., \& Lotfi, R. E. Z. A. (2010). Correlation between Emotional Intelligence and Socio-emotional Adjustment in Pre-university Girl Students in Tehran in 2008. Pajoohandeh Journal, 14(5), 255-261. 
Sells, N. (2007). A social intelligence primer. Journal of Sales and Marketing Management, 159(8), 10.

Smith, T. (2003). The metaphysical case for honesty. Journal of Value Inquiry, 37(4), 517-531.

Snyder, C. R. (2002). Hope theory: Rainbows in the mind. Psychological inquiry, 13(4), 249-275.

Snyder, C. R., \& Lopez, S. J. (Eds.). (2001). Handbook of positive psychology. Oxford university press.

Snyder, C. R., Harris, C., Anderson, J. R., Holleran, S. A., Irving, L. M., Sigmon, S. T., ... \& Harney, P. (1991). The will and the ways: development and validation of an individual-differences measure of hope. Journal of personality and social psychology, 60(4), 570-585.

Snyder, C. R., \& Forsyth, D. R. (1991). Handbook of social and clinical psychology: The health perspective. Pergamon Press.

Takahashi, M., \& Overton, W. F. (2002). Wisdom: A culturally inclusive developmental perspective. International Journal of Behavioral Development, 26(3), 269-277.

Tamannaeifar, M. R., \& Behzadmoghaddam, R. (2016). Examination of the relationship between life satisfaction and perceived social support. International Academic Journal of Organizational Behavior and Human Resource Management, 3(1), 8-15.

Ten Brinke, L., \& Porter, S. (2012). Cry me a river: identifying the behavioral consequences of extremely high-stakes interpersonal deception. Law and Human Behavior, 36(6), 469.

Thoits, P. A., \& Hewitt, L. N. (2001). Volunteer work and well-being. Journal of Health and Social Behavior, 42(2), 115-131.

Valle, M. F., Huebner, E. S., \& Suldo, S. M. (2004). Further evaluation of the Children's Hope Scale. Journal of Psychoeducational Assessment, 22(4), 320-337.

Vallerand, R. J. (2012). The role of passion in sustainable psychological well-being. Psychology of wellBeing: Theory, research and practice, 2(1), 1-21.

Van Boven, L., \& Gilovich, T. (2003). To do or to have? That is the question. Journal of personality and social psychology, 85(6), 1193.

Zirkel, S. (2000). Social intelligence: The development and maintenance of purposive behavior. In: R. Bar-On and J. D. A. Parker, eds. The handbook of emotional intelligence: Theory, development, assessment, and application at home, school, and in the workplace. San Francisco, CA: JosseyBass.

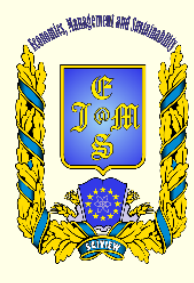

() 2016-2021, Economics, Management and Sustainability. All rights reserved. This open access article is distributed under a Creative Commons Attribution (CC-BY) 4.0 license.

You are free to:

Share - copy and redistribute the material in any medium or format Adapt - remix, transform, and build upon the material for any

purpose, even commercially.

The licensor cannot revoke these freedoms as long as you follow the license terms.

Under the following terms:

Attribution - You must give appropriate credit, provide a link to the license, and indicate if changes were made.

You may do so in any reasonable manner, but not in any way that suggests the licensor endorses you or your use.

No additional restrictions

You may not apply legal terms or technological measures that legally restrict others from doing anything the license permits.

Economics, Management and Sustainability (ISSN: 2520-6303) is published by Scientific Publishing House "CSR",

Poland, EU and Scientific Publishing House "SciView", Poland

Publishing with JEMS ensures:

- Immediate, universal access to your article on publication

- High visibility and discoverability via the JEMS website

- Rapid publication

- Guaranteed legacy preservation of your article

- Discounts and waivers for authors in developing regions

Submit your manuscript to a JEMS at http://jems.sciview.net or submit.jems@sciview.net

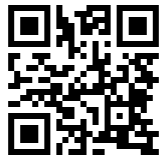

